\title{
PENULISAN ARTIKEL ILMIAH BERBASIS PENELITIAN TINDAKAN KELAS (PTK) UNTUK MENINGKATKAN KUALITAS PENGAJARAN DAN PEMBELAJARAN DI SMA BANJARMASIN KALIMANTAN SELATAN
}

\author{
Syahmani $^{1}$, Rusmansyah ${ }^{2}$, Atiek Winarti ${ }^{3}$, Almubarak ${ }^{4}$ \\ 1,2,3,4Pendidikan Kimia, Fakultas Keguruan dan Ilmu Pendidikan \\ Universitas Lambung Mangkurat \\ Email: almubarak_kimia@ulm.ac.id
}

\begin{abstract}
Action research is a form of collective self-reflection of a social situation to improve reasoning and justice in the situation in which the research is conducted. Classroom Action Research is a practical research intended to improve classroom learning. This research is one of the efforts of the teacher or practitioner in the form of various activities carried out to improve and or improve the quality of learning in the classroom. The purpose of this activity is to provide a comprehensive description of classroom action research and how research results are oriented towards scientific articles as a media for publicity and dissemination of knowledge. The method used in the activity is the delivery of material in stages with two-way communication between the resource person and participants, discussion, and brainstorming. Participants in the activity are high school teachers in Pelaihari City, South Kalimantan. The results obtained illustrate that the teacher understands the purpose of writing articles, writing scientific articles right up to the process of publishing articles, and motivation as energy in civilizing writing scientific articles to produce quality, creative, and innovative graduates. That is, teachers already have a mindset about the importance of articles and their publications as a PTK research output, so that this is able to broaden teachers' insights.
\end{abstract}

Keywords: scientific paper, action research, quality of teaching and learning.

\begin{abstract}
Abstrak. Action research atau penelitian tindakan kelas (PTK) merupakan bentuk refleksi diri secara kolektif terhadap sebuah situasi sosial guna meningkatkan penalaran dan keadilan dalam situasi di tempat dilakukannya penelitian tindakan tersebut. Penelitian Tindakan Kelas adalah penelitian praktis yang dimaksudkan untuk memperbaiki pembelajaran di kelas. Penelitian ini merupakan salah satu upaya guru atau praktisi dalam bentuk berbagai kegiatan yang dilakukan untuk memperbaiki dan atau meningkatkan mutu pembelajaran di kelas. Tujuan kegiatan ini yakni untuk memberikan dekripsi secara komprehensif tentang penelitian tindakan kelas (PTK) dan bagaimana hasil penelitian berorientasi artikel ilmiah sebagai media publikais dan penyebarluasan ilmu pengetahuan. Metode yang digunakan dalam kegiatan yaitu penyampaian materi secara bertahap dengan komunikasi dua arah antara narasumber dan peserta, diskusi, dan brainstorming. Peserta dalam kegiatan yaitu para guru SMA di Kota Pelaihari Kalimantan Selatan. Hasil yang diperoleh menggambarkan bahwa guru mengerti tentang tujuan menulis artikel, penulisan artikel ilmiah yang benar sampai proses publikasi artikel, dan motivasi sebagai energi dalam membudayakan menulis artikel ilmiah untuk menghasilkan lulusan yang berkualitas, kreatif, dan inovatif. Artinya, pengajar sudah memiliki pola pikir mengenai pentingnya artikel dan publikasinya sebagai luaran penelitian PTK, sehingga ini mampu memperluas wawasan pengajar.
\end{abstract}

Kata kunci: artikel ilmiah, penelitian tindakan kelas, kualitas pengajaran dan pembelajaran.

\section{PENDAHULUAN}

UU Nomor 14 Tahun 2005 tentang guru dan dosen menjelaskan bahwa Guru adalah pendidik profesional dengan tugas utama mendidik, mengajar, membimbing, mengarahkan, melatih, menilai, dan mengevaluasi peserta didik pada pendidikan anak usia dini jalur pendidikan formal, pendidikan dasar, dan pendidikan menengah. Guru profesional berarti pekerjaan atau kegiatan yang dilakukan oleh seseorang dan menjadi sumber penghasil kehidupan, dan memiliki seperangkat pengetahuan, keterampilan, dan perilaku yang harus dimiliki, dihayati, dan dikuasai disebut kompetensi. Pernyataanpernyataan tersebut memberikan gambaran bahwa seorang guru memiliki peran penting dalam membangun Bangsa Indonesia yang melahirkan generasi muda dalam menghadapi arus globalisasi yang bersifat dinamis. Peran tersebut juga dinilai penting mengingat banyaknya permasalahan belajar di sekolah dan 
hadirnya pengaruh sosial media yang bersifat tanpa batas.

Konten UU di atas jika ditelisik pada indikator "profesional" dan "mengevaluasi" tentu menjadi bagian yang mesti ditonjolkan dalam diri seorang pengajar. Indikator pertama yakni, keprofesionalan tidak hanya riwayat studi pengajar seperti asal Perguruan Tinggi (PT) tempat menimbah ilmu, tetapi sejauh mana ilmu yang diperoleh diterapkan dalam aspek pendidikan untuk menyelesaikan permasalahanpermasalahan khususnya dalam kelas. Jika dinilai dari aspek keilmuan seorang pengajar, maka penelitian merupakan salah satu poin penilaian bagaimana pengajar mengintegrasikan keilmuan tersebut dalam proses pembelajaran di kelas. Hal ini penting karena penelitian merupakan salah satu sumber belajar yang bisa digunakan oleh pengajar (guru) dalam proses pembelajaran sehingga proses pembelajaran yang dialami oleh siswa terkesan nyata dan kontekstual (Hamzah Uno, 2010). Artinya, penelitian merupakan hal wajib yang mesti dilaksanakan oleh pengajar agar mampu mengidentifikasi dan menganalisa sejauh mana kualitas pengajaran yang dilaksanakan, bagaimana peningkatan aktivitas belajar siswa ataupun pengajar itu sendiri, sejauh mana tujuan pembelajaran dicapai, bagaimana respon dan motivasi belajar siswa (Caltabiano, Hajhashemi, \& Anderson, 2017; Rodríguez, Díaz, Gonzalez, \& González-Miquel, 2019) berdasarkan strategi pengajaran yang digunakan (Yazicilar \& Güven, 2009), dan gambaran pencapaian akademik siswa melalui evaluasi pembelajaran (Williams, 2018).

Indikator kedua yakni proses evaluasi, di mana tugas pengajar adalah melakukan evaluasi secara sistematis yang bertujuan untuk mengatahui hasil pengajaran dan pembelajaran yang telah dilaksanakan. Secara konten, proses evaluasi pembelajaran dan penelitian pada dasarnya memiliki tujuan yang sama yakni mengetahui gambaran kualitas pengajar dan siswa melalui hasil pembelajaran yang secara reguler dilaksanakan. Sehingga, penelitian dinilai menjadi alternatif cara agar pengajar secara bertahap memperbaiki kualitas pembelajaran di kelas dan melatih siswa dalam memecahkan permasalahan setiap siswa. Penelitian Tindakan Kelas (PTK) atau Action Research merupakan penelitian yang bisa digunakan oleh setiap pengajar di lingkungan sekolah sebagai dasar dalam mencapai tujuan pembelajaran dan aspek lain yang telah dijelasakan berenaan dengan penelitian dan evaluasi (Mulia \& Suwarno, 2016; Ptk \& Ptk, 2014; Widayati, 2019).

Penerapan PTK diperkuat oleh beberapa ahli yang menyebutkan bahwa penelitian tindakan kelas adalah bentuk refleksi diri secara kolektif terhadap sebuah situasi sosial guna meningkatkan penalaran dan keadilan dalam situasi di tempat dilakukannya penelitian tindakan tersebut (kemmis \& Taggart, 1988). Kemudian, siswojo (1997) Mengembangkan dari pendapat mereka bahwa yang melakukan refleksi diri adalah partisipan yang terdiri dari guru, murid, maupun kepala sekolah. Situasi sosial yang dimaksud adalah dalam bidang pendidikan guna memperbaiki rasionalitas serta kebenaran terkait praktik pendidikan yang dilakukan sendiri, pengertian mengenai praktik tersebut, hingga situasi tempat dilaksanakannya praktik. Diperkuat oleh John Elliot (1982) bahwa penelitian tindakan kelas adalah sebuah kajian mengenai suatu permasalahan sosial yang dilakukan untuk meningkatkan unsur tindakan di dalamnya yang dimana semua prosesnya berpengaruh dan diperlukan sebagai bahan evaluasi untuk berkembang ke arah profesional. Secara keseluruhan adalah PTK mampu menjadi pendorong bagi pengajar untuk lebih memerhatikan praktik mengajarnya (Mulia \& Suwarno, 2016)agar menjadi lebih kritis dan bersedia memperbaiki, memperbaharui, atau melakukan perubahan demi kualitas pendidikan yang lebih baik, efektif, dan berkualitas (Widayati, 2019).

Berbicara terkait uraian di atas, bahwa penelitian yang telah dilaksanakan oleh pengajar tidak boleh berhenti hanya sampai pada tahap penulisan laporan sehingga tidak memiliki bentuk implikasi terhadap dunia pendidikan. Hasil penelitian PTK yang dilaksanakan oleh pengajar sebaiknya dituangkan dalam tulisan dan dipublikasikan sebagai bentuk penyebarluasan ilmu pengetahuan. Penulisan karya ilmiah menjadi artikel ilmiah dan publikasi merupakan strategi yang baik bagi pengajar agar secara konkret bisa menilai kompetensi diri sebagai 
pengajar. Luaran penelitian seperti artikel ilmiah termasuk salah satu bentuk keprofesionalan dan kompetensi guru sebagai pendidik. Hal ini disebutkan dalam Permen PAN dan RB Nomor 16 Tahun 2009 bahwa, Pengembangan keprofesian berkelanjutan adalah pengembangan kompetensi Guru yang dilaksanakan sesuai dengan kebutuhan, bertahap, berkelanjutan untuk meningkatkan profesionalitasnya (Ainon Mardhiah, Yusrizal, 2017; Legiman, 2016; Widayati, 2019). Artinya, publikasi ilmiah atau penyebarluasan ilmu pengetahuan melalui karya tulis ilmiah merupakan kewajiban seorang guru, dengan tujuan sebagai wadah penyegaran ilmu yang dimiliki dan bentuk kontribusi dalam mencerdaskan anak bangsa.

Pentingnya publikasi ilmiah contohnya, dalam pembelajaran kimia ini ditunjukkan melalui laman www.sciencedirect.com dengan keyword: chemistry learning dan learning process terlihat bahwa 3.353 artikel tentang pembelajaran kimia di athun 2018 dan terhitung januari sampai april ini 2019 sebanyak 1709 jumlah artikel yang membahas isu tersebut. Data statistik tersebut menggambarkan antusiasme peneliti dalam mengkaji pembelajaran kimia. Namun, artikel mengenai proses pembelajaran tahun 2018 sebanyak 54.374 artikel dan tahun ini terhitung 28.564 artikel yang terbit. Artinya, melaksanakan penelitian dan menuangkan dalam artikel ilmiah bisa menjadi solusi bagi pengajar atau peneliti dalam memperbaiki kualitas pembelajaran di sekolah. Hal ini dikarenakan saat ini pembelajaran sedang mengarah ke pembelajaran secara digital (Dawson, n.d.; Sukor, Osman, \& Abdullah, 2010) sehingga pengajar perlu menyesuaikan kondisi psikologi (Torre, 2009) anak zaman sekarang dengan konsep pembelajaran yang diterapkan atau sesuai gaya belajar mereka (Jahanbakhsh, 2012).

Permasalahan dalam kegiatan ini yaitu (1) bagaimana mekanisme Penelitian Tindakan Kelas (PTK) ?, dan (2) bagaimana hasil penelitian PTK dituangkan dalam karya tulis ilmiah dan publikasi ?. Tujuan kegiatan yang dilakukan terkait proses penelitian tindakan kelas (PTK) yaitu (1) Memberikan pengetahuan tentang proses dan peran PTK sebagai strategi peningkatan kualitas pengajaran dan pembelajaran di ingkungan sekolah, (2) Memberikan penjelasan mengenai tujuan menulis artikel sebagai bentuk penyegaran ilmu pengetahuan dan perbaikan kualitas pembelajaran, (3) Menunjukkan sistematika penulisan artikel ilmiah yang benar sampai proses publikasi artikel, dan (3) Memotivasi para pengajar (guru) untuk membudayakan menulis artikel ilmiah untuk menghasilkan lulusan yang berkualitas, kreatif, dan inovatif.

\section{METODE PELAKSANAAN}

Kegiatan yan dilaksanakan ini merupakan kegiatan pengabdian pada masyarakat dengan melaksanakan beberapa tahap seperti melakukan rapat internal dengan tim terkait bagaimana dans eperti apa teknis pelaksanaan kegiatan Pengabdian kepada Masyarakat (PkM). Kemudian, tahap berikutnya adalah mengkomunikasikan topik PkM kepada mitra yang tentu disesuaikan dengan kondisi permasalahan mitra. Selain itu, kegiatan PkM ini dilaksanakan di aula SMAN 1 Pelaihari dengan konteks penyajian materi secara dua arah agar suasana PkM menjadi lebih hikmat. Sesi tanya jawab pun menjadi bagian yang penting dalam pelaksanaan PkM di mana guru-guru diberikan kesempaatn untuk berdiskusi dan ataupun bertanya tentang permasalahan yang dialami. Berikut rangkaian secara rinci pelaksanaan PkM yang akan dilakukan.

\section{A. Persiapan Kegiatan Pengabdian Masyarakat \\ Berikut ini merupakan Tahapan Persiapan Kegiatan Pengabdian Masyarakat yakni Penulisan artikel ilmiah dan publikasi.}




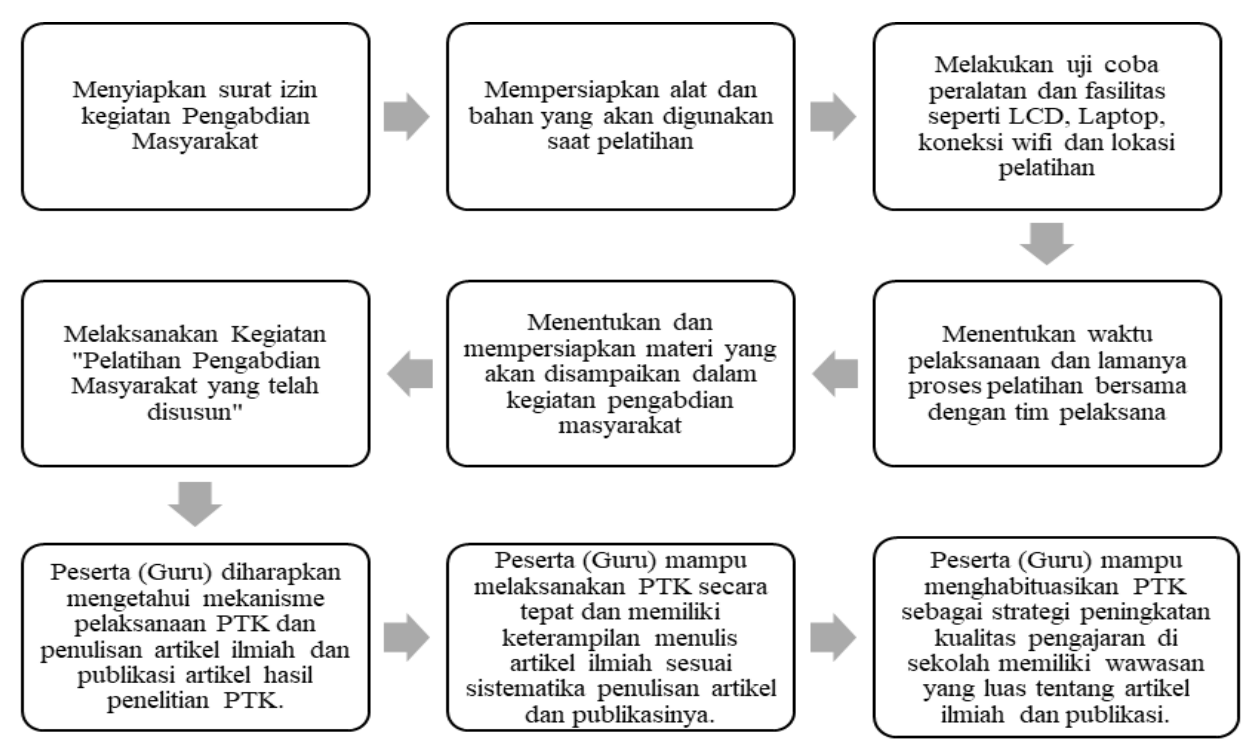

Gambar 7. Proses Pelaksanaan Kegiatan Pengabdian Pada Masyarakat

\section{B. Pelaksanaan kegiatan Pengabdian Pada Masyarakat}

Pelaksanaan kegiatan pengabdian masyarakat akan berlangsung di SMA Negeri 1 Pelaihari dan target peserta yang akan hadir adalah 30 orang guru SMA. Kegiatan berupa penyampaian materi dan mekanisme pelaksanaan Penelitian Tindakan Kelas (PTK), praktek langsung mengenai sistematika penulisan artikel ilmiah, dan tata cara publikasi artikel. Pemilihan sampel ini didasari karena pentingnya melaksanakan PTK di lingkungan sekolah dan publikasi artikel ilmiah bagi guru. Selain melaksanakan PTK, pengajar (guru) dibekali pengetahuan tentang penulisan artikel ilmiah dan

Narasumber terkait kegiatan pengabdian masyarakat ini adalah Dr. Syahmani, M.Si. dan Dr. Rusmansyah, M.Pd, narasumber tersebut merupakan pakar dalam bidang penelitian pendidikan, sehingga relevan dengan esensi kegiatan yang dilaksanakan. Pembahasan yang diangkat seputar penentuan masalah yang ada dalam kelas, cara penyelesaian masalah, penulisan artikel ilmiah, dan publikasi dari artikel yang telah ditulis. Tujuan dari pelatihan penulisan artikel adalah sebagai evaluasi pembelajaran dan juga pembimbingan kepada para guru untuk memperluas wawasan mengenai hakikat penelitian, sehingga karir pendidik mereka berkembang dan lebih profesional. proses pubikasi berdasarkan hasil PTK yang telah dilaksanakan.

\section{HASIL DAN PEMBAHASAN}

Pengabdian pada masyarakat yang telah dilakukan berlokasi di SMA Negeri 1 Pelaihari, Kabupaten Tanah Laut, Kalimantan Selatan. Kegiatan ini dilaksanakan dalam waktu sehari, yaitu pada hari Kamis, 18 Juli 2019 pukul 10.00 WITA-selesai di aula besar SMA Negeri 1 Pelaihari. Peserta kegiatan terdiri dari para guru dengan jumlah sekitar 30 orang. Dari peserta yang hadir dapat disimpulkan bahwa jumlahnya sesuai dengan target. Acara dibuka dengan sambutan dari Wakil Kepala Sekolah, Rif'qon Hidayah, S.Pd dan dilanjutkan oleh Koordinasi Prodi Pendidikan Kimia, Dr. Rusmansyah, M.Pd.

Adapun rincian materi kegiatan pengabdian masyarakat adalah adalah membahas tentang:

1. Pentingnya melakukan evaluasi dalam kelas dengan cara menentukan masalah yang ada;

2. Bagaimana cara menyelesaikan masalah berdasarkan penelitian-penelitian lain yang telah berhasil dilakukan;

3. Langkah-langkah melakukan penyelesaian masalah dan penelitian mandiri dalam bentuk penelitian tindakan kelas (PTK);

4. Mendesiminasikan dan mempublikasikan hasil penelitian dalam bentuk artikel ilmiah pada Jurnal Nasional/Internasional dna atau Seminar Nasional/Internasional, dan 
5. Bagaimana memotivasi diri untuk produktif melaksanakan penelitian guna meningkatkan kualitas siswa serta guru secara profesional.

Kegiatan yang disusun berbasis tatap muka dan diskusi dua arah antara narasumber dan peserta dengan tujuan agar terjalin komunikasi mendalam mengenai permasalahan yang terjadi di lingkungan sekolah. Pada tiap pemaparan materi oleh narasumber, terdapat dua sesi, yaitu sesi penyampaian materi dan sesi tanya jawab. Setelah narasumber memaparkan materi hingga selesai, para guru sangat antusias mengajukan beberapa pertanyaan. Pertanyaan yang diberikan adalah tentang bagaimana tata cara melakukan penelitian berbasis PTK dan tentang bagaimana cara meningkatkan semangat dan motivasi untuk melakukan penelitian. Pertanyaan yang diajukan menunjukkan bahwa para guru kurang berpengalaman dalam melakukan PTK serta penulisan artikel ilmiah dan publikasinya. Pertanyaan-pertanyaan tersebut semakin berkualitas dengan adanya sharing hal-hal yang beragam seperti, manajemen kelas yang baik, identifikasi masalah belajar siswa, bagaimana meningkatkan keterampilan siswa, pangkat akademik, dll.

\section{A. Pembahasan Pelaksanaan Kegiatan}

Kegiatan pengabdian masyarakat yang dilakukan oleh Prodi Pendidikan Kimia dari Universitas Lambung Mangkurat dilaksanakan dengan memaparkan langsung mengenai pentingnya melakukan evaluasi pembelajaran dan menjadikannya sebagai bahan penelitian tindakan kelas. Selain membahas tentang penelitian tindakan kelas, cara meningkatkan motivasi diri untuk melakukan penelitian juga menjadi fokus utama kegiatan. Metode kegiatan yakni brainstorming, ceramah, dan diskusi secara langsung mengenai langkah-langkah dalam penelitian tindakan kelas. PTK merupakan salah satu metode penelitian yang perlu melalui banyak tahapan serta membutuhkan waktu yang tidak sedikit, sehingga PTK sebaiknya dilakukan langsung oleh guru yang memahami dengan baik tenteng situasi dan kondisi dalam kelas, terutama keadaan para siswa.
Materi tentang PTK disampaikan oleh narasumber Dr. Syahmani, M.Si dan Dr. Rusmansyah, M.Pd di mana mereka menjelaskan secara mendalam tentang langkah-langkah yang harus dilakukan selama proses penelitian. Selain itu, narasumber juga mengungkapkan pentingnya hasil penelitian untuk dipubliaksikan sebagai metode penyebarluasan ilmu pengetahuan. Hal ini berhubungan karena adanya kesulitan dalam pencarian literasi dan pengalaman menulis yang sudah tak pernah diasah sejak penulisan skripsi semasa menjalani kuliah. Meskipun, ditengah proses penjelasan materi terjadi peristiwa mati listrik, namun kegiatan tetap berjalan sesuai dengan konsep yang telah direncanakan. Artinya, hambatan tersebut tidak sepenuhnya menghalangi semangat peserta untuk memperoleh materi.

Pemaparan PTK yang dijelaskan narasumber membuka pemikiran guru untuk meneliti masalah yang terjadi dalam pembelajaran dan cara mengoptimalkan kompetensi siswa selanjutnya. Materi PTK yang telah dipaparkan mendalam menuju ke sesi kedua, yaitu tanya jawab. Diskusi terjadi semakin dalam ketika guru menjelaskan secara spesifik permasalahan yang terjadi. Para guru rata-rata kurang paham tentang standar pelaksanaan penelitian khususnya PTK/action research. Padahal, PTK merupakan salah satu penelitian yang mampu membantu guru mengidentifikasi karakter belajar siswa sehingga siswa mampu belajar sesuai kebutuhan. Selain itu, PTK juga mampu meningkatkan profesionalitas guru dalam mengelola pembelajaran di kelas. Permasalahan berikutnya yaitu, guru minim pengetahuan tentang hasil penelitian yang berpotensi menjadi jantung dalam penulisan artikel ilmiah. Narasumber menjelaskan bahwa setiap penelitian memerlukan literatur yang tentu memiliki unsur kebaruan, pengalaman dalam pengajaran, dan bimbingan dari yang telah menguasai bidang. Oleh karena itu, posisi narasumber pada kegiatan pengabdian adalah memberi pengarahan mengenai segala sesuatu yang belum atau tidak dipahami guru sebelumnya. 

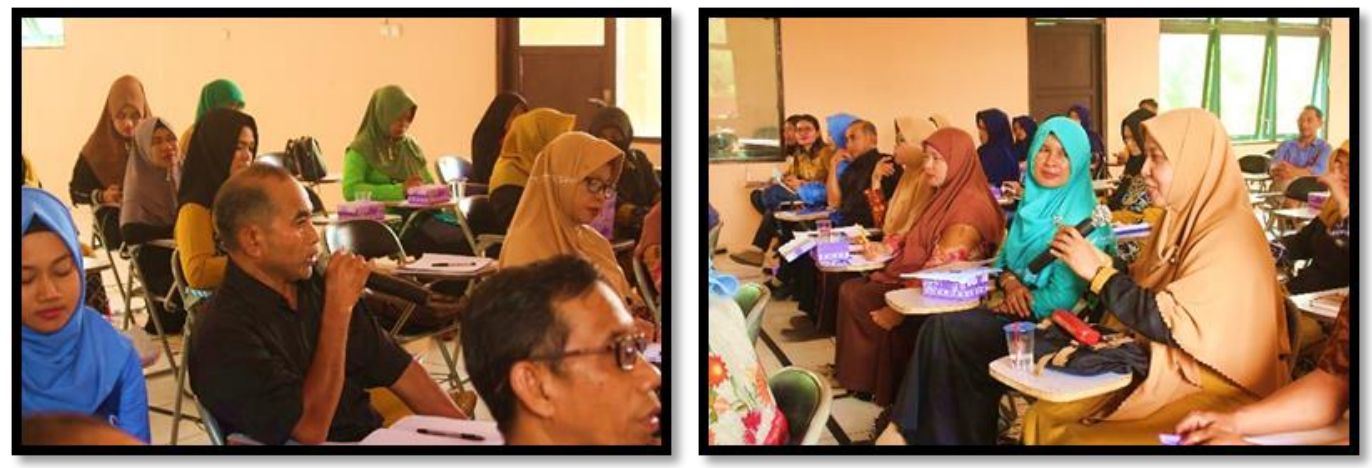

Gambar 6. Tanya Jawab Narasumber dan Para Peserta (Guru)

Permasalahan mendasar di SMA Negeri 1 Pelaihari, antara lain:

1. Guru-guru mengalami masalah kepangkatan karena ketidaktahuan mereka bagaimana mengelola masalah kelas menjadi suatu latar belakang penelitian,

2. Keterampilan siswa masih dinilai kurang karena ketidakmampuan siswa menginterpretasi apa yang telah dijelaskan oleh guru mereka, sehingga guru kesulitan memberikan penguatan agar siswa lebih kompeten dari sebelumnya,

3. Secara konteks pembelajaran, sebenarnya guru telah melakukan penilaian terhadap masalah belajar siswa tapi tidak mengintegrasikan secara utuh dalam konteks penelitian, dan

4. Ketidaktahuan proses standar dan teknik penulisan artikel melalui hasil penelitian (penelitian tindakan kelas/ action research).

Narasumber juga memberikan contoh berupa bagaimana masalah dalam kelas dapat menjadi motivasi guru untuk memperbaikinya. Ketika guru menemukan bahwa siswa sulit memberikan perhatian penuh selama pembelajaran atau sulit menerima pembelajaran, maka seorang guru tidak lantas merasa lelah menghadapi situasi demikian, melainkan semakin terpacu membuat siswa tersebut menjadi lebih baik. Salah satu caranya adalah dengan mulai membaca dan mencari penelitian-penelitian yang telah berhasil dilakukan untuk diterapkan ke dalam kelas untuk pembelajaran-pembelajaran selanjutnya.

Pemberian materi oleh narasumber kedua berlangsung cukup ramai dengan adanya sharing mengenai waktu yang diperlukan oleh guru untuk mengajar sangat banyak, sebanyak 24 jam pembelajaran, sehingga mereka sulit untuk mengatur waktu melakukan penelitian. Belum pula mereka harus memfokuskan diri kepada keluarga di luar jam kerja yang sangat padat. Berdasarkan masalah pribadi dari guru, narasumber menyatakan bahwa PTK memerlukan proses yang cukup panjang, sehingga guru dapat selalu memiki waktu untuk ikut berproses secara perlahan. Ketika guru mendapat motivasi, motivasi tersebut harus segera dituangkan sebelum motivasi dan semangatnya hilang. Dengan adanya proses yang perlahan demikian, semakin lama akan dapat dihasilkan penelitian yang berkualitas.

Kasus di atas merupakan salah satu masalah yang dihadapi oleh sebagian besar guru, terutama oleh mereka yang sudah berkeluarga dan senior. Setelah itu, narasumber selalu memberikan kesempatan kepada peserta untuk mengungkapkan masalah-masalah yang dihadapi dalam proses pembelajaran. Kemudian, narasumber memberi pandangan dan saran terkait masalah yang diungkapkan oleh peserta. Narasumber memotivasi guru agar segera dapat memulai kegiatan PTK demi kemajuan para siswa dan guru yang bersangkutan. 


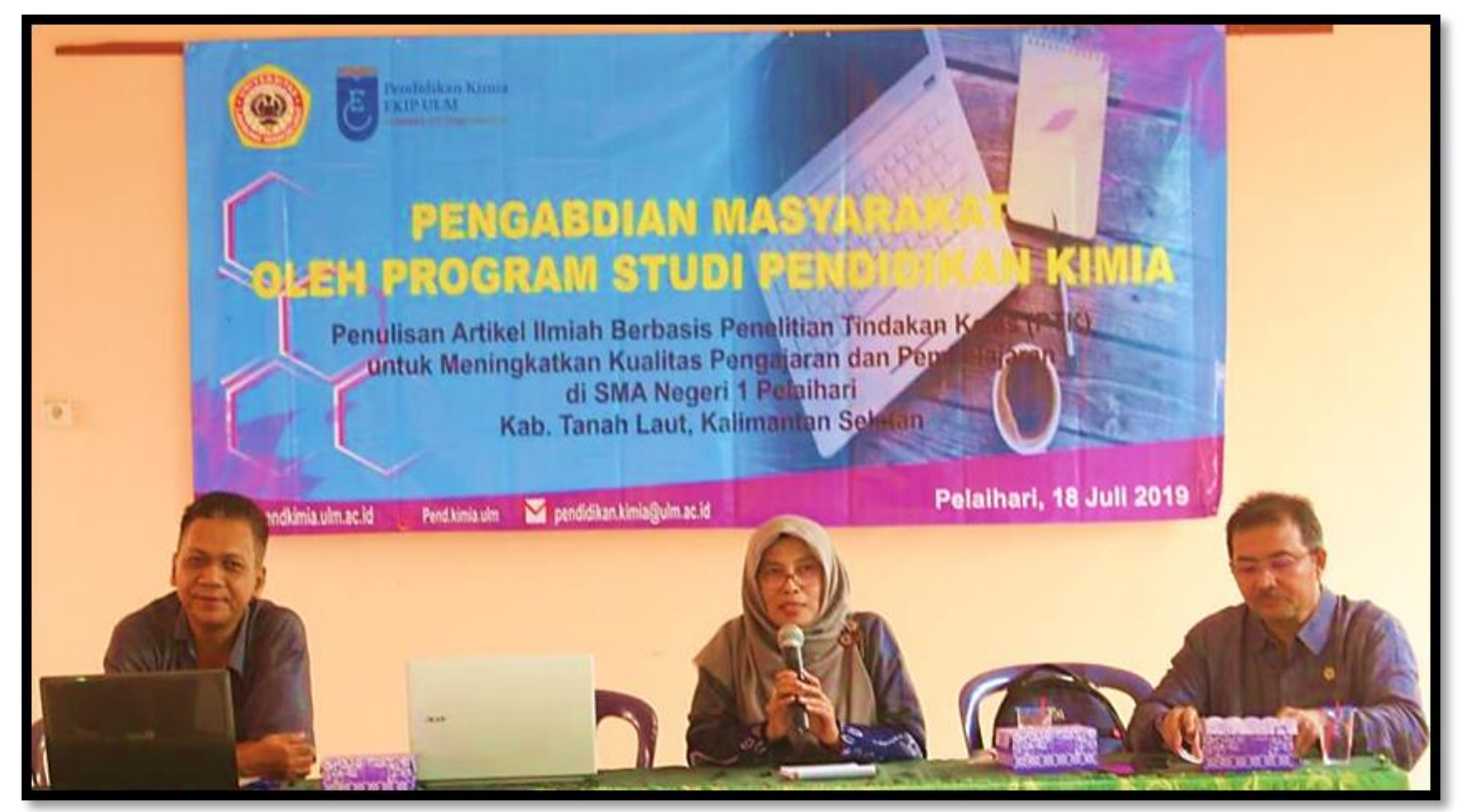

Gambar 6. Motivasi Penulisan Artikel Ilmiah oleh Dr. Hj. Atiek Winarti, M.Pd., M.Sc.

Hal-hal tersebut di atas merupakan faktor utama yang menyebabkan kurang optimalnya proses pembelajaran di kelas dan secara tidak langsung berdampak pada peningkatan kualifikasi akademik pengajar. Artinya, karena guru tidak melakukan penelitian di kelas sebagai bentuk evaluasi pembelajaran mereka, maka guru tidak mampu menilai perkembangan siswanya, bagaimana pengelolaan kelas yang baik untuk mencapai tujuan pembelajaran serta pangkat akademik yang unadvanced. Dampaknya adalah guru secara karir tidak bisa melanjutkan kepangkatan akademik seperti, jabatan fungsional, golongan, dan kompetensi lainnya yang berpengaruh terhadap kesejahteraan guru.

Sehubungan dengan hal di atas bahwa narasumber memberikan pandangan bahwa penulisan artikel ilmiah beserta publikasinya merupakan hal yang penting dilakukan oleh pengajar. Penjelasan yang mendalam tentang fungsi artikel ilmiah sebagai salah satu kegiatan keprofesionalan guru cukup ramai menjadi bahan diskusi. Tanggapan para guru adalah tentang bagaimana sebenarnya tata cara membuat artikel dan publikasinya. Guru kesulitan memperoleh informasi mengenai penerbitan artikel jurnal sebagai media publikasi bagi kepangkatan akademik mereka. Jadi, kenaikan pangkat para guru menjadi terhambat oleh karena tidak dipahaminya prosedural dalam publikasi atau penerbitan artikel.
Tahapan akhir kegiatan pengabdian masyarakat ini merupakan tahap refleksi dan evaluasi bagi seluruh guru terkait peningkatan profesionalisme guru, potensi siswa, dan masyarakat sekolah lainnya (Avraamidou, 2016, 2019; Nilsson \& Karlsson, 2019; Pekdağ, 2010). Melalui diadakannya kegiatan pengabdian masyarakat, guru pada akhirnya memiliki kesadaran diri tentang pentingnya melaksakan penelitian sebagai bentuk evaluasi pembelajaran, agar proses pembelajaran di kelas tidak hanya tentang mencerdaskan anak bangsa, tapi bagaimana membangun budaya belajar yang baik untuk mengahsilkan lulusan yang unggul dan pengajar yang profesional. Selain peningkatan akademik guru, kegiatan berikut juga menambah wawasan guru mengenai penulisan artikel ilmiah yang benar, jenis-jenis publikasi ilmiah, dan media-media penyebarluasan ilmu pengetahuan seperti, international confferences, seminar nasional, jurnal ilmiah terakreditasi dan terindeks, dst.

The big goal yang diharapkan dari kegiatan pengabdian kepada masyarakat ini adalah guru memiliki keterampilan (Hikmah, Yamtinah, Ashadi, \& Indriyanti, 2018; Kilic, Sezen, \& Sari, 2012; Muntaner-Mas, VidalConti, Sesé, \& Palou, 2017), pengetahuan (Adilah \& Budiharti, 2015; Avraamidou, 2019; Beijaard, Meijer, \& Verloop, 2004), dan motivasi (Aksela, 2005; Avraamidou, 2016; Tehseen \& U1 
Hadi, 2015) terkait penulisan artikel ilmiah dan publikasinya. Jadi, pengelolaan pembelajaran, penelitian, artikel ilmiah, publikasi, dan peningkatan kompetensi guru secara tidak sadar saling berhubungan dan merupakan satu kesatuan dalam konteks penyelenggaraan pendidikan di sekolah. Hal-hal tersebut sebagai bentuk perwujudan profesionalitas pengajar dan evaluasi dalam pengoptimalan kompetensi guru serta pengembangan potensi siswa, sehingga pendidikan di SMA Negeri 1 Pelaihari, Kabupaten Tanah Laut mengalami peningkatan baik dari sisi guru maupun siswanya. Konsep kegiatan yang dibawa semoga bisa menjadi langkah awal perbaikan kualitas pendidikan di SMA Negeri 1 Pelaihari agar mencapai tujuan pendidikan nasional sesuai tuntutan UU Nomor 20 Tahun 2003.

Di akhir acara, para guru yang merupakan peserta diberikan angket yang berisi beberapa pertanyaan beserta pendapat dan saran untuk dapat digunakan untuk meningkatkan kualitas kegiatan pengabdian masyarakat Prodi Pendidikan Kimia, Universitas Lambung Mangkurat selanjutnya. Seluruh guru yang menghadiri acara merasa sangat puas dan senang akan keberlangsungan kegiatan karena mereka merasa sangat perlu memahami lebih dalam tentang PTK dan penulisan serta publikasi artikel ilmiah. Para guru bahkan mengharapkan jika kegiatan pengabdian masyarakat ini tidak berhenti sampai pemaparan materi semata, melainkan ada pelatihan tentang pembuatan PTK secara langsung. Mereka bersemangat untuk menghadiri dan berperan sebagai peserta lagi jika acara tersebut diadakan kembali di SMA Negeri 1 Pelaihari.

\section{SIMPULAN DAN SARAN}

\section{A. Kesimpulan}

Berdasarkan kegiatan pengabdian masyarakat yang telah dilaksanakan, maka diperoleh kesimpulan bahwa, kegiatan Pengabdian kepada Masyarakat (PkM) dengan topik proses dan peran PTK sebagai strategi

peningkatan kualitas pengajaran dan pembelajaran di lingkungan sekolah merupakan alternatif cara dalam melakukan pembaharuan dalam peningkatan profesionalitas pengajar. Meknaisme yang ditempuh oleh kegiatan ini adalah melaksanakan observasi, sosialisasi mengenai PTK dan Publikasinya, Brainstorming terkait isu yang dibahas, refleksi, tanya jawab, dna evaluasi kegiatan. Kemudian, Guru mengerti tentang tujuan menulis artikel, penulisan artikel ilmiah yang benar sampai proses publikasi artikel, dan motivasi sebagai energi dalam membudayakan menulis artikel ilmiah untuk menghasilkan lulusan yang berkualitas, kreatif, dan inovatif. Artinya, pengajar sudah memiliki pola pikir mengenai pentingnya artikel dan publikasinya sebagai luaran penelitian PTK, sehingga ini mampu memperluas wawasan pengajar.

\section{B. Saran}

Kegiatan Pengabdian Masyarakat di SMAN 1 Pelaihari, Kabupaten Tanah Laut, Kalimantan Selatan merupakan pedoman dan acuan bagi setiap individu yang terlibat di lingkungan sekolah untuk sadar dan memahami pentingnya penelitian, penulisan, dan publikasi artikel ilmiah. Kegiatan ini akan menjadi dasar bahwa pihak sekolah harus memikirkan mengenai perbaikan kualitas pembelajaran agar menghasilkan lulusan yang berkulitas. Perbaikan ini tidak hanya diperuntukkan bagi guru, namun semua pihak yang terlibat di dalam dan di luar lingkungan sekolah termasuk masyarakat umum.

\section{DAFTAR PUSTAKA}

Adilah, D. N., \& Budiharti, R. (2015). Model Learning Cycle 7E Dalam Pembelajaran IPA Terpadu. Prosiding Seminar Nasional Fisika Dan Pendidikan Fisika (SNFPF) Ke6, 6(1), 212-217. Retrieved from www.jurnal.fkip.uns.ac.id/index.php/prosfis 1/article/view/7769

Ainon Mardhiah, Yusrizal, N. U. (2017). Peningkatan Profesionalitas Guru Melalui. Jurnal Administrasi Pendidikan Realita Volume 15, No. 2 Tahun 2017, 4(2), 1-11. https://doi.org/10.1016/j.det.2012.08.002

Aksela, M. (2005). Supporting Meaningful Chemistry Learning and Higher-order Thinking through Computer-Assisted Inquiry: A Design Research Approach. In University of Helsinki.

Avraamidou, L. (2016). Studying Science 
Teacher Identity. In L. Avraamidou (Ed.), Studying Science Teacher Identity (THeoritical, Methodological, and Empirical Exploration (pp. 1-14). Rotterdam: Sense Publisher.

Avraamidou, L. (2019). Stories we live, identities we build: how are elementary teachers' science identities shaped by their lived experiences? Cultural Studies of Science Education, 14(1), 33-59. https://doi.org/10.1007/s11422-017-9855-8

Beijaard, D., Meijer, P. C., \& Verloop, N. (2004). Reconsidering research on teachers' professional identity. Teaching and Teacher Education, 20(2), 107-128. https://doi.org/10.1016/j.tate.2003.07.001

Caltabiano, N., Hajhashemi, K., \& Anderson, N. (2017). Multiple Intelligences, Motivations and Learning Experience Regarding VideoAssisted Subjects in a Rural University. International Journal of Instruction, 11(1), 167-182.

https://doi.org/10.12973/iji.2018.11112a

Dawson, M. R. W. (n.d.). OPEL (open paths to enriched learning).

Hikmah, N., Yamtinah, S., Ashadi, \& Indriyanti, N. Y. (2018). Chemistry teachers' understanding of science process skills in relation of science process skills assessment in chemistry learning. Journal of Physics: Conference Series, 1022(1). https://doi.org/10.1088/17426596/1022/1/012038

Jahanbakhsh, R. (2012). Learning Styles and Academic Achievement: a Case Study of Iranian High School Girl's Students. Procedia - Social and Behavioral Sciences, 51(1988), 1030-1034. https://doi.org/10.1016/j.sbspro.2012.08.28 2

Kilic, D., Sezen, N., \& Sari, M. (2012). A Study of Pre-Service Science Teacher's Graphing Skills. Procedia - Social and Behavioral Sciences, 46, 2937-2941. https://doi.org/10.1016/j.sbspro.2012.05.59 3

Legiman, M. P. (2016). Penelitian Tindakan Kelas (Ptk). Widyaiswara LPMP D.I. Yogyakarta, 1-15.
Mulia, D. S., \& Suwarno. (2016). Ptk (Penelitian Tindakan Kelas) Dengan Pembelajaran Berbasis Kearifan Lokal Dan Penulisan Artikel Ilmiah Di Sd Negeri Kalisube, Banyumas. Khazanah Pendidikan Jurnal Ilmiah Kependidikan, Vol. IX, No. 2 (Maret 2016) PTK, IX(2), 11. Retrieved from http://jurnalnasional.ump.ac.id/index.php/kh azanah/article/view/1062/983

Muntaner-Mas, A., Vidal-Conti, J., Sesé, A., \& Palou, P. (2017). Teaching skills, students' emotions, perceived control and academic achievement in university students: A SEM approach. Teaching and Teacher Education, 67, $1-8$. https://doi.org/10.1016/j.tate.2017.05.013

Nilsson, P., \& Karlsson, G. (2019). Capturing student teachers' pedagogical content knowledge (PCK) using CoRes and digital technology. International Journal of Science Education, 41(4), 419-447. https://doi.org/10.1080/09500693.2018.155 1642

Pekdağ, B. (2010). Alternative Methods in Learning Chemistry: Learning with Animation, Simulation, Video and Multimedia. Journal of Turkish Science Education, 7(2), 111-118.

Ptk, J. S., \& Ptk, S. (2014). JURNAL SERAMBI PTK ( Jurnal Pendidikan , Pembelajaran , dan Penelitian Tindakan Kelas ) Dewan Redaksi Ketua: Armi Sekretaris : Nurlena Andalia Anggota Redaksi Evi Apriana Anita Noviyanti Jailani Muhammad Saleh Muhammad Usman Hambali Musriadi M . Ridhwan . 1(1).

Rodríguez, M., Díaz, I., Gonzalez, E. J., \& González-Miquel, M. (2019). Reprint of: Motivational active learning: An integrated approach to teaching and learning process control. Education for Chemical Engineers, 26 , $8-13$. https://doi.org/10.1016/j.ece.2019.01.002

Sukor, N. S., Osman, K., \& Abdullah, M. (2010). Students' achievement of Malaysian 21st Century Skills in Chemistry. Procedia Social and Behavioral Sciences, 9, 12561260.

https://doi.org/10.1016/j.sbspro.2010.12.31 
6

Tehseen, S., \& Ul Hadi, N. (2015). Factors Influencing Teachers' Performance and Retention. Mediterranean Journal of Social Sciences, (March). https://doi.org/10.5901/mjss.2015.v6n1p233 Torre, J. de la. (2009). A Cognitive Diagnosis Model for Cognitively Based MultipleChoice Options. Applied Psychological Measurement, 33(3), 163-183. https://doi.org/10.1177/0146621608320523

Widayati, A. (2019). Penelitian Tindakan Kelas. Jurnal Pendidikan Akuntansi Indonesia, 6(1), https://doi.org/10.21831/jpai.v6i1.1793

Williams, D. P. (2018). Measuring the Effectiveness of an Open Ended TeamBased Induction Task. New Directions in the Teaching of Physical Sciences, 13(13), $1-7$.

https://doi.org/10.29311/ndtps.v0i13.2680

Yazicilar, Ö., \& Güven, B. (2009). The effects of learning style activities on academic achievement, attitudes and recall level. Procedia - Social and Behavioral Sciences, l(1), 2578-2583. https://doi.org/10.1016/j.sbspro.2009.01.45 5 